\title{
Effects of IFRS adoption on tax avoidance
}

\section{Renata Nogueira Braga}

Universidade de São Paulo, Faculdade de Economia, Administração e Contabilidade, Departamento de Contabilidade e Atuária, São Paulo, SP, Brazil

Received on 11.12.2016 - Desk acceptance on 01:09.2017 - $2^{\text {nd }}$ version approved on 05.18.2017

\section{ABSTRACT}

This study investigates the association between mandatory International Financial Reporting Standards (IFRS) adoption and corporate tax avoidance. In this study, tax avoidance is defined as a reduction in the effective corporate income tax rate through tax planning activities, whether these are legal, questionable, or even illegal. Three measures of tax avoidance are used and factors at the country and firm level (that have already been associated with tax avoidance in prior research) are controlled. Using samples that range from 9,389 to 15,423 publicly-traded companies from 35 countries, covering 1999 to 2014, it is found that IFRS adoption is associated with higher levels of corporate tax avoidance, even when the level of book-tax conformity required in the countries and the volume of accruals are controlled, both of which are considered potential determinants of this relationship. Furthermore, the results suggest that after IFRS adoption, firms in higher booktax conformity environments engage more in tax avoidance than firms in lower book-tax conformity environments. It is also identified that engagement in tax avoidance after IFRS adoption derives not only from accruals management, but also from practices that do not involve accruals. The main conclusion is that companies engage more in tax avoidance after mandatory IFRS adoption.

Keywords: IFRS, tax avoidance, book-tax conformity, tax planning.

$\overline{\text { *Article presented at the XVI International Conference in Accounting, São Paulo, SP, Brazil, July } 2016 .}$ 


\section{INTRODUCTION}

The introduction of an international accounting standard aims to harmonize the financial information companies present. The hope is that mandatory International Financial Reporting Standards (IFRS) adoption increases transparency and comparability in the preparation and presentation of general purpose financial statements, thus enabling the capital and credit markets to function more efficiently (Brüggemann, Hitz, \& Sellhorn, 2013). In light of the expected benefits of IFRS adoption, more than 120 countries have already adopted this set of international norms (IFRS Foundation, 2017). While various studies seek to identify whether there are informational benefits from IFRS adoption and what these are, the taxation related effects of this adoption have been scarcely explored. Simone (2015) notes that there is little research examining the relationship between IFRS adoption and tax planning.

This study therefore investigates the taxation effects of IFRS adoption; more specifically, whether IFRS adoption around the world is associated with higher levels of tax avoidance among publicly-traded companies. It also investigates: (i) how the relationship between mandatory IFRS adoption and corporate tax avoidance behaves in high and low book-tax conformity environments; and (ii) whether IFRS adoption has an impact on companies' engagement in tax avoidance through accruals management, practices that do not involve accruals, or both.

Initially, the idea of adopting a new accounting standard would not lead to consequences in the area of taxation, especially considering that the aim of IFRS is to provide more useful information to users in general and that such a set of norms does not aim to serve any specific needs, such as those of tax authorities. However, alterations in taxable income and in tax planning activities, especially in activities that increase levels of tax avoidance, may have occurred with the adoption of IFRS.

With IFRS adoption, countries with a high level of book-tax conformity that used local generally accepted accounting principles (GAAP) as a basis or starting point for calculating taxable income, and/or that had strong links between reported earning and taxable income, needed to define their rules for elaborating financial statements for tax purposes. Many jurisdictions that adopted IFRS for the purposes of preparing and presenting financial statements continued to require the local GAAP to be kept as a starting point for calculating taxes (Deloitte, 2010). Along these lines, Chan, Lin, and Mo (2010), Chan, Lin, and Tang (2013), Chen and Gavious (2015), and Karampinis and Hevas (2013) have identified that after IFRS adoption some distancing occurred between the rules for the preparation and presentation of general purpose financial statements and those for taxation purposes; that is, there was a reduction in the level of book-tax conformity.

Atwood, Drake, Myers, and Myers (2012), Chan et al. (2010, 2013), Desai (2005), and Tang (2015) indicate that a decrease in the level of book-tax conformity increases the level of corporate tax avoidance. Researchers that have identified this relationship have mainly based their findings on the fact that managers in high conformity environments face a book-tax trade-off in which any decision to discretionarily reduce taxable income affects the value of the profit that will be reported to external users. According to Desai (2005), Hanlon, Laplante and Shevlin (2005), and Hanlon and Shevlin (2005), when the level of book-tax conformity decreases, managers do not face the book-tax trade-off and there is thus no longer this greater constraint on them reporting profits in the most convenient way. Strong evidence that IFRS adoption may have affected tax avoidance levels can thus be identified via the indirect relationship between these two variables; IFRS adoption has reduced required levels of book-tax conformity and lower book-tax conformity is associated with greater tax avoidance.

Another condition that may establish a relationship between mandatory IFRS adoption and increased levels of tax avoidance is the possible increase in discretionary and non-discretionary accruals identified after IFRS adoption. Ahmed, Neel, and Wang (2013) and Lin, Riccardi, and Wang (2012) documented an increase in the aggressiveness of accruals after IFRS adoption. Atwood et al. (2012), Frank, Lynch, and Rego (2009), and Wilson (2009) identified that greater aggressiveness of accruals is associated with increased tax avoidance. Given that an increase in accruals was identified after IFRS adoption and that aggressiveness of accruals is associated with a higher level of tax avoidance, then IFRS adoption may have indirectly contributed to increasing tax avoidance. Other evidence that IFRS adoption can affect the activities that increase tax avoidance was identified by Simone (2015). This author found an increase in profit transfers for taxation purposes, from jurisdictions with higher tax burdens to jurisdictions with lower tax burdens, after the adoption of IFRS.

According to De George, Li, and Shivakumar (2016), the first studies on IFRS mostly present the benefits of adoption for companies and countries in terms of 
improved transparency, investments between countries, comparability of financial statements, reduced cost of capital, and an increase in foreign analysts. More recent studies attribute the occurrence of at least one of the benefits mentioned to other factors, such as changes in a country's enforcement. It is noted that the literature on IFRS has sought to identify the impacts of adopting this accounting standard on the quality of financial information and its repercussions. This study thus intends to fill gaps in the scarce literature on IFRS adoption and its taxation effects.

Hanlon et al. (2005) verified that both reported earnings and taxable income provide additional information for investors. Thus, it is of key importance for investors and capital market users to know whether taxable income, which provides information used in the decision-making process of resource allocation, is being manipulated to reduce tax expenses. Knowing if IFRS adoption is associated with a higher level of tax avoidance is also of interest to the governments of countries adopting the new set of accounting norms and countries that are thinking about adopting them, since it enables them to know how the behavior of the revenues derived from corporate income tax may have been or are affected by IFRS adoption. The study can thus contribute to the literature on this topic, which is of interest to governments, companies, and investors, and which contains little empirical evidence.

\section{LITERATURE REVIEW AND HYPOTHESIS}

\subsection{Tax Avoidance}

There are no universally accepted definitions or constructs for tax avoidance, which is a challenge for research in the area. The term can mean different things to different people. The lack of a universally accepted definition should not, however, prevent research on the topic; on the contrary, the more better studies are carried out, the greater the possibility of an acceptable definition taking form (Hanlon \& Heitzman, 2010).

For Slemrod (2004), tax avoidance is defined as legal actions that aim to reduce tax liabilities. The limitation of the definition to only legal actions is debated, especially in light of the argument of the difficulty in determining which activities executed in order to reduce tax burdens are legal and which are not (Atwood et al., 2012; Dyreng, Hanlon, \& Maydew, 2008; Hanlon \& Heitzman, 2010). Supporting the discussions regarding the difficulty in distinguishing between legal and illegal activities, Dyreng et al. (2008) note the existence of many areas in which tax law is unclear, especially for complex transactions, which can result in questionable interpretations.

Hanlon and Heitzman (2010) therefore mention that they do not technically distinguish the legal act of avoiding taxation from the illegal act, for two reasons: (i) most of the behaviors in question revolve around transactions that are generally considered as technically legal and (ii) the legality of tax avoidance transactions is generally determined after the fact. Along these farreaching lines, Chen, Chen, Cheng, and Shevlin (2010) define tax avoidance as management that aims to reduce taxable income through tax planning activities, whether these are legal, questionable, or even illegal. The term tax avoidance, as in Atwood et al. (2012), Dyreng et al. (2008), and Hanlon and Heitzman (2010), is used in this study as a generic term, covering the terms "tax non-compliance", "tax sheltering", "tax evasion", and "tax aggressiveness", since there is no intention to suggest any irregularity on the part of companies, but rather to learn if they are able to avoid paying corporate income tax.

\subsection{IFRS and Tax Avoidance}

According to the IFRS Foundation Constitution (2013), the aim of the International Accounting Standards Board (IASB) is to develop, by taking the public interest into account, a single set of high quality, comprehensible, executable, and globally accepted accounting standards based on clearly articulated principles. These standards should require high quality, transparent, and comparable information in order to help investors, capital market participants around the world, and accounting information users to take economic decisions. In observing the aim of the IASB, it is noted that the focus of IFRS is to enable financial statements to be elaborated in a way that they provide useful information for the economic decisionmaking of users in general, and that IFRS are not intended to serve the specific needs of tax authorities.

Initially, the idea of adopting a new accounting standard would not lead to taxation consequences; however, IFRS adoption may have affected companies' taxable income. In adopting IFRS, countries with a high level of book-tax conformity needed to define between: (i) also using IFRS as a basis for calculating taxable income, thus maintaining levels of conformity high; (ii) using IFRS to prepare and present general purpose financial 
statements and maintaining local GAAP as the basis for calculating taxable income, thus reducing the level of conformity, and (iii) creating standards for tax purposes independent of the GAAP used, thus reducing the level of conformity. In adopting IFRS, countries with a low level of conformity could: (i) use IFRS to prepare and present general purpose financial statements and maintain the already existing legislation for tax purposes, thus maintaining a low level of conformity or (ii) also start using IFRS as the basis for calculating taxable income, thus increasing the level of conformity.

It is therefore verified that depending on the level of book-tax conformity and the country's decision to maintain or modify this level of conformity after adopting IFRS, companies' taxable income could be affected. According to Deloitte (2010), many jurisdictions that adopted IFRS with the aim of preparing and presenting financial statements continued to require the local GAAP to be kept as the basis for calculating tax. Thus, the studies from Chan et al. (2010, 2013), Chen and Gavious (2015), and Karampinis and Hevas (2013) mention that after IFRS adoption, there was some distancing between the financial statements for general purposes and those for tax purposes. One of the factors that could explain the decision of countries to keep the old local rules for calculating tax is the fact that IFRS gives managers greater discretion in choosing the accounting methods that best reflect companies' economic and financial reality (Chan et al., 2010) in order to achieve the goal of making financial statements more useful for external users. The discretion given to managers to choose the methods to be used in preparing of general purpose financial statements is questioned and generally not accepted by tax authorities for calculating taxable income. The reduction in the level of book-tax conformity experienced by various countries when IFRS was adopted may have had an impact on the activities that increase levels of tax avoidance, given that there is empirical evidence that a low level of conformity can lead to an increase in the level of tax avoidance (Atwood et al., 2012; Chan et al., 2010, 2013; Desai, 2005; Tang, 2015).

When there is a high level of book-tax conformity, an increase in financial earnings generally implies an increase in taxable income, thus resulting in a higher level of tax liabilities for companies, which they would presumably prefer to avoid (Hanlon et al., 2005). Thus, a reduction in taxable income generally implies a reduction in the accounting earning reported in the capital markets (Hanlon \& Shevlin, 2005). If companies opt for transactions that generate book-tax differences in order to achieve the best of both worlds (high reported earnings and low taxable income), it could raise suspicions that one or possibly both measures of earnings have been opportunistically reported (Hanlon et al., 2005). In contrast, when the level of booktax conformity is low, managers do not face the book-tax trade-off and there is thus not the greater constraint to report earnings in the most convenient way for them. In this setting, companies more easily avoid paying tax by using strategies that create book-tax differences, which are less costly strategies. As a result, companies located in countries with a low level of book-tax conformity tend to engage more in tax avoidance (Atwood et al., 2012).

Another indirect relationship between IFRS adoption and levels of tax avoidance can be established via increases in discretionary and non-discretionary accruals. Greater aggressiveness of accruals was identified after the adoption of IFRS (Ahmed et al., 2013; Lin et al., 2012). This increase in the aggressiveness of accruals may be due to the greater flexibility given to managers after IFRS adoption, since this set of accounting standards is based on principles and does not have any detailed guides for implementation. Given that managers have incentives to exploit accounting discretion in their favor, increased discretion after IFRS adoption will probably lead to more earnings management, ceteris paribus (Ahmed et al., 2013).

Atwood et al. (2012) suggest that tax avoidance and earnings management are like two sides of the same coin, given that managers have incentives for both: increasing reported earnings and decreasing taxable income. Frank et al. (2009) thus show a strong positive relationship between tax avoidance and aggressiveness in the preparation and presentation of general purpose financial statements. The authors found that if a company has the possibility of managing its reported earnings upwards and its taxable income downwards in the same period, it will engage in this behavior. Given that IFRS adoption is related to an increase in the aggressiveness of accruals and that a higher level of aggressiveness of accruals is positively associated with a higher level of tax avoidance, IFRS adoption may have contributed to an increase in tax avoidance.

Another point that warrants attention is the increase in reported earnings via accruals after the adoption of IFRS. Increased reported earnings can cause an increase in tax avoidance, without there in fact being an increase in the practices that avoid paying tax. The tax avoidance metrics that involve the effective tax rate (ETR) generally take pre-tax earnings as their denominator; if these earnings increase and tax remains constant, the effective tax rate will be reduced due to the increase in the denominator and an increase in tax avoidance will be identified, but not due to specific behaviors to reduce taxation. It bears mentioning, however, that if an increase in reported earnings resulting from an increase in accruals, whether 
discretionary and/or non-discretionary, remains in the long run, then the company is avoiding taxation on this overestimated reported earnings, thus reflecting the practice of tax avoidance (Hanlon \& Heitzman, 2010).

IFRS adoption can also affect the level of tax avoidance of entities due to other factors. Simone (2015) verified that subsidiary companies in the European Union became more involved in profit transfers for tax reasons after the adoption of IFRS, estimating that on average those subsidiaries that mandatorily adopted IFRS transferred $11.5 \%$ more profit in relation to subsidiaries in the preadoption years and subsidiaries that did not adopt IFRS. The European Union countries follow the guidelines of the Organization for Economic Cooperation and Development (OECD) for setting transfer pricing. The preferred method is to obtain information on specific contractual terms celebrated with or by independent companies for comparable transactions. Since the availability of this information is limited, multinational entities generally use reference transfer prices, identifying a set of observable, economically comparable, and independent companies, which use similar accounting standards to compare profit margins. Thus, the adoption of a single standard such as IFRS by various jurisdictions expands the set of companies that can be used as potential references and can enable multinational entities to choose more favorable references to support transfer pricing with tax advantages (Simone, 2015).

Based on the reasons mentioned, which show that mandatory IFRS adoption may have positively affected levels of corporate tax avoidance, the following hypothesis is formulated:

$\mathbf{H}_{\mathbf{1}}$ : mandatory IFRS adoption is associated with a higher level of tax avoidance.

\section{METHODOLOGY}

\subsection{Regression Model Specification}

In order to test the effect of IFRS adoption on tax avoidance, the following model was used:

$$
\operatorname{Tax}_{\text {Avoid }_{i, t}}=\alpha_{t}+\alpha_{\text {ind }}+\alpha_{1} \operatorname{IFRS}_{j, t}+\sum \alpha_{K} \text { Control }_{i, j, t}+e_{i, t}
$$

in which: $i$ indexes firm; $t$ indexes time (year); $j$ indexes country; TaxAvoid $=$ measure of tax avoidance (models 2,3 , and 4 presented below); $\alpha_{t}=$ year-fixed effect; $\alpha_{\text {ind }}$ $=$ industry-fixed effect based on the classification of 30 industries from Fama-French; IFRS = dummy variable that takes the value of 1 after mandatory IFRS adoption by country $j$ and 0 in other cases; and Control $=$ control variables at the country level and at the firm level. 


\subsubsection{Dependent variable — tax avoidance}

The first metric for tax avoidance used in this study indicates the total taxation that a company is able to avoid in relation to the amount calculated by applying the tax rate in the company's country of origin on pre-tax earnings before exceptional items. This metric was proposed by Atwood et al. (2012):

$$
T A 1_{i, t}=\frac{\left[\sum_{t-2}^{t}(P T E B X x \tau)_{i, t}-\sum_{t-2}^{t} C T P_{i, t}\right]}{\sum_{t-2}^{t} P T E B X_{i, t}}
$$

in which: $i$ indexes firm; $t$ indexes time (year); PTEBX - pre-tax earnings before exceptional items; $\tau=$ homecountry statutory corporate income tax rate; and CTP = current tax payable.

PTEBX is the value of pre-tax earnings (Item PI code referring to the Compustat databases, which are the reference for the following items in this article) minus the value of exceptional items (Item SPI). The values for $\tau$ were collected manually from EY (2015), KPMG (2015), and the Tax Foundation (2015). CTP is the current tax expense (Item TXC) minus the variation in income tax payable (Item TXP). If there are no data regarding current tax expenses, total tax expenses minus deferred tax expenses (Item TXT - Item TXDI) are used, if available.

As in Atwood et al. (2012), TA1 was estimated using a three year window, since this period was considered adequate for reducing the effects of items that are reverted in only one year and does not restrict the size of the sample like the use of a five or 10 year window would. To calculate the TA1 variable, three consecutive years of positive PTEBX are required.

The other tax avoidance metrics (TA2 and TA3) used in this study were based on the proposal from Tang (2013). To estimate tax avoidance, the difference between the home-country statutory corporate income tax rate and the the current effective tax rate were used, with the effective rate being measured by dividing the current tax expense by pre-tax earnings before exceptional items (model 3) and by dividing the current tax expense by operating cash flow (model 4).

$$
\begin{gathered}
T A 2_{i, t}=\boldsymbol{\tau}_{i, j}-\frac{C T E_{i, t}}{\operatorname{PTEB} X_{i, t}} \\
T A 3_{i, t}=\boldsymbol{\tau}_{i, j}-\frac{C T E_{i, t}}{O C F_{i, t}}
\end{gathered}
$$

in which: $\mathrm{CTE}=$ current tax expense; $\mathrm{OCF}=$ operating cash flow. All of the other variables have already been previously defined.

To measure the CTE, first data on the current tax expense (Item TXC) were used, and in cases in which such data were not available, the total tax expense minus the deferred tax expense (Item TXT - Item TXDI) was used. $\tau$ and PTEBX were measured in the same way as in model 2. OCF is earnings before extraordinary items (Item IB) minus total accruals. Total accruals were measured in the following way: the variation in current assets that are not cash flow (Item ACT - Item CHE) minus the variation in the current liabilities that are not loans and financing (Item LCT - Item DCL) minus depreciation (Item DP). In agreement with Tang (2015), observations with a negative OCF were eliminated. Effective rates of current tax expense with a value of greater than 1 were substituted by 1 . To measure the variables TA1, TA2, and TA3, observations with a negative current tax expense were eliminated. To remove the influence of potential outliers, the winsorize technique was used for the variables TA1, TA2, and TA3 in the $1^{\text {st }}$ and $99^{\text {th }}$ percentiles for each year. 


\subsubsection{Control variables.}

Control variables that have already presented a significant association with tax avoidance in previous studies were used. The control variables were divided into control variables at the country level and at the firm level. At the country level, the following were controlled: (i) home-country statutory corporate income tax rate, collected manually from the EY (2015), KPMG (2015), and Tax Foundation (2015) websites, and (ii) institutional factors: legal enforcement (LegEnf), investor rights (InvRig), and ownership concentration (OwnConc), developed by Kaufmann and Kraay (2015), Djankov, La Porta, Lopez-de-Silanes, and Shleifer (2008), and La Porta, Lopez-de-Silanes, Shleifer, and Vishny (1998), respectively. The LegEnf variable is calculated as the average of three variables: regulatory quality, rule of law, and the level of corruption in a country. It varies from -2.5 to +2.5 and the lower it is, the lower the legal enforcement in the country. The InvRig variable is an indicator of investor rights; it varies from 0 to 6 and the higher the indicator, the greater investor rights. The OwnConc variable represents the ownership concentration in a country, and the higher it is, the greater that ownership concentration.

At the firm level the following were controlled: (i) profitability (Pre-TaxROA), measured as pre-tax earnings before exceptional items (Item PI - Item SPI) divided by lagged total assets; (ii) firm size (LogSize), using the natural log of total assets; leverage (Leverage), calculated as total debt (Item DLTT + Item DLC) divided by total assets (Item AT); and (iv) growth in sales (SalesGrth), as the variation in revenue divided by lagged revenue (variation in Item REVT divided by Item REVT lagged). To measure the LogSize variable, all of the assets were converted into dollars using the daily conversion rate available from the Institutional Brokers' Estimate System (I/B/E/S) database. For all of the other control variables at the firm level, the winsorize technique was used in the $1^{\text {st }}$ and $99^{\text {th }}$ percentiles for each year.

\subsection{Book-Tax Conformity Regression Model}

Given that IFRS adoption may have caused a reduction in book-tax conformity, which in turn may cause in an increase in tax avoidance, it was verified how the association between IFRS adoption and tax avoidance behaves when the level of conformity between reported earnings and taxable income is kept constant and whether this association differs in high and low conformity environments. To do so, the level of book-tax conformity in the countries over the years was measured using the metric proposed by Atwood, Drake, and Myers (2010). The authors modeled book-tax conformity as the amount of the variation in the current tax expense that is not explained by the variation in pre-tax earnings.

$$
C T E_{i, t}=\theta_{0}+\theta_{1} P T B I_{i, t}+\theta_{2} D I V_{i, t}+e_{i, t}
$$

in which: $i$ indexes firm; $t$ indexes time (year); CTE = current tax expense; $P T B I=$ pre-tax earnings; $D I V=$ total dividends; and $e=$ error.

In the original model there was also the ForPTBI variable, which is the estimated pre-tax foreign earnings. The authors, however, estimated the model without this variable and the results were qualitatively similar. Due to the permanence of the results without this variable and the limitation of the databases used, in which the data needed to estimate it were not available, the variable was removed from the model. CTE is the total tax expense (Item TXT) minus the deferred tax expense (Item TXDI). If there are no data regarding the TXDI or TXT, the current tax expense (Item TXC) is used, if available. Total dividends (Item DVT) were included in the model to control for potential cross-sectional differences in the current tax expenses related to the distribution of dividends. For countries with fewer than eight observations with DIV $\neq 0$ in a particular year, the values that were different to zero in that year are set equal to zero. In cases in which there are missing values, it is assumed that DIV is equal to zero. In order to control differences in the cross-sectional scale, CTE, PTBI, and DIV are divided by average total assets (Item AT). All of the firm-year observations with negative PTBI or CTE were removed. In order to remove potential outliers, the winsorize technique was used in the $1^{\text {st }}$ and $99^{\text {th }}$ percentiles of the variables CTE, PTBI, and DIV for each year.

The estimated model is for country-year in order to enable changes in tax rates and in book-tax conformity between countries and within the same country over time. A higher (lower) root mean-squared error (RMSE) indicates lower (higher) book-tax conformity. For the regression analysis, the countries were ranked (decreasing 
ranking) every year based on the RMSE from model 5. As in Atwood et al. (2010), the highest RMSE in the year was ranked as 0 and the lowest RMSE in the year was ranked as $n-1$, in which $n$ is the number of countries included in that year. Then it was divided by $n-1$ so that the ranking scale varied between 0 and 1 ; those countries with higher positions in the ranking in a given year have greater book-tax conformity. The scaled result of the ranking is the BTaxC variable.

To verify how the association between IFRS adoption and tax avoidance behaves when the level of book-tax conformity is kept constant, the following model was used:

$$
\operatorname{TaxAvoid}_{i, t}=\alpha_{t}+\alpha_{i n d}+\alpha_{1} \operatorname{IFRS}_{j, t}+\alpha_{2} \operatorname{BTaxC}_{j, t}+\sum \alpha_{K} \operatorname{Control}_{i, j, t}+e_{i, t}
$$

in which: $\mathrm{B} \operatorname{tax} \mathrm{C}=$ level of book-tax conformity required, measured in accordance with model 5. All of the other variables have already been previously defined.

To verify if the association between mandatory IFRS adoption and tax avoidance differs between high and low book-tax conformity environments, model 7 was used, and then the difference of coefficient test was carried out between coefficients $\alpha_{1}$ and $\alpha_{2}$ of the following model.

$$
\begin{gathered}
\text { TaxAvoid }_{i, t}=\alpha_{t}+\alpha_{i n d}+\alpha_{1} \text { IFRSXHighBTaxC }_{j, t}+\alpha_{2} \text { IFRSxLowBTaxC }_{j, t}+\alpha_{3} \text { BTaxC }_{j, t} \\
+\sum \alpha_{K} \text { Control }_{i, j, t}+e_{i, t}
\end{gathered}
$$

in which: HighBTaxC $=1$ if $B$ TaxC is above the median and 0 if it is below the median; LowBTaxC $=1$ if BTaxC is below the median and 0 if it is above the median. All of the other variables have already been previously defined.

To determine the countries that are above and below the median, an increasing ranking of the countries that compose the sample was carried out based on the average book-tax conformity required for each country during the study period. The countries below the ranking median are those that present low book-tax conformity and the countries above the ranking median are those that present high book-tax conformity.

\subsection{Regression Model with Accruals}

In order to achieve the objective of verifying whether IFRS adopted has had an impact on companies' engagement in tax avoidance through accruals management, practices that do not involve accruals, or both, total accruals is included in regression model 6. By including total accruals it is possible to control the relationship between an increase in the aggressiveness of accruals and tax avoidance and between an increase in reported earnings through accruals after IFRS adoption and tax avoidance.

$$
\operatorname{TaxAvoid}_{i, t}=\alpha_{t}+\alpha_{\text {ind }}+\alpha_{1} \operatorname{IFRS}_{j, t}+\alpha_{2} \text { BTaxC }_{j, t}+\alpha_{3} \operatorname{TotAcC}_{i, t}+\sum \alpha_{K} \text { Control }_{i, j, t}+e_{i, t}
$$

in which: TotAcc = total accruals. The other variables have already been previously defined.

TotAcc is calculated in accordance with Atwood et al. (2012) and is obtained using the sum of the variation in working capital that is not cash flow $(\triangle \mathrm{WC})$, the variation in net non-current operating assets $(\triangle \mathrm{NCO})$, and the variation in net financial assets $(\triangle \mathrm{FIN})$. WC is measured using current operating assets (Item ACT - Item CHE) minus current operating liabilities (Item LCT - Item DLC) divided by total average assets [(Item $\left.\left.\mathrm{AT}_{\mathrm{t}}+\mathrm{Item}_{\mathrm{AT}} \mathrm{t-1}\right) / 2\right]$.
NCO is obtained from non-current operating assets (Item $\mathrm{AT}$ - Item ACT - Item IVAEQ - Item IVAO) minus non-current operating liabilities (Item LT - Item LCT - Item DLTT) divided by total average assets. FIN is measured by financial assets (Item IVST + Item IVAEQ + Item IVAO) minus financial liabilities (Item DLTT + Item DLC + Item FUSEO) divided by total average assets. To control potential outliers, the winsorize technique was applied in the $1^{\text {st }}$ and $99^{\text {th }}$ percentiles of the variables $\Delta \mathrm{WC}, \Delta \mathrm{NCO}$, and $\Delta \mathrm{FIN}$ for each year. 


\subsection{Sample Selection and Data}

The study sample was selected based on all of the firm-year observations, from 1999 to 2014, with data available from the Compustat Global and North America databases, in order to compute the variables in the models used in the study. All the observations from countries that are not in Djankov et al. (2008) and La Porta et al. (1998) were eliminated, since these studies developed metrics for the institutional factors that were used as control variables at the country level in this study, and all of the observations for the countries that did not adopt IFRS in the time interval studied. Subsequently, all of the observations for companies from the financial sector were eliminated, since in various countries the timeframe for IFRS adoption for this sector is different. For companies that changed reporting currency during the period analyzed, the firm-year observations from the year prior to the change in currency were eliminated, given the existence of control variables calculated based on the variation in a particular item.

Finally, following the research protocol adopted by Atwood et al. (2012), in order to generate greater comparability of the results at least 20 useful observations per country-year were required. Applying these criteria generated a sample composed of observations for 35 countries, which in terms of economic representativeness were responsible for $36.5 \%$ of global gross domestic product (GDP) in 2015, according to The World Bank (2017).

The beginning of the study period was set in accordance with the year in which there are available data regarding the corporate income tax rate for the sample countries. The period was extended to 2014 to include most countries that have already adopted IFRS in the study. Table 1 presents all of the sample countries and the year of IFRS adoption for each one.

\section{RESULTS}

\subsection{Descriptive Statistic}

Table 1 presents the median for the dependent variables in the study in an individualized way for each one of the 35 countries analyzed. To estimate the median for the dependent variable $T A 1,41,823$ observations of 9,389 companies included in regression model 1 were used. To estimate the median for the dependent variable TA2 (TA3), 82,091 $(81,786)$ observations of $14,766(15,423)$ companies included in regression model 1 were used. As in Atwood et al. (2012), the median for the TA1 variable is high (low) for Australia, South Africa, and South Korea (Hong Kong and Singapore). Besides these countries, in this study, Argentina, Brazil, Nigeria, Pakistan, and Sri Lanka (Finland, Ireland, Taiwan, and Turkey) also present a high (low) median for the TA1 variable.
The descriptive statistics were measured in the 20022014 interval for the TA1 variable and all of the control variables and in the 2000-2014 interval for the TA2 and TA3 variables. The data regarding the 1999 financial year were used to calculate variables that needed data for the year prior to their measurement. As the TA1 variable is measured over three years, in order to calculate TA 1 for 2002, data for 2002, 2001, and 2000 were needed. The fact that the TA1 variable is calculated over three years explains the notable difference between the number of observations used in the regressions that include this variable and the number of observations used in the regressions that involve the TA2 and TA 3 variables. Table 1 also reveals the dispersion in the sample between the 35 countries. It is noted that only the observations for Taiwan exceed the $10 \%$ representativeness of the sample. 
Table 1 Sample composition, International Financial Reporting Standards adoption date, and median for the dependent variables.

\begin{tabular}{|c|c|c|c|c|c|c|c|c|c|c|}
\hline Country & Adoption date & $\mathbf{n}_{1}$ & Percent & TA1 & $\mathbf{n}_{2}$ & Percent & TA2 & $\mathrm{n}_{3}$ & Percent & TA3 \\
\hline Argentina & $12 / 31 / 2012$ & 325 & 0.78 & 0.350 & 585 & 0.71 & 0.350 & 611 & 0.75 & 0.350 \\
\hline Australia & $12 / 31 / 2005$ & 2,085 & 4.99 & 0.255 & 5,122 & 6.24 & 0.300 & 5,404 & 6.61 & 0.300 \\
\hline Austria & $12 / 31 / 2005$ & 310 & 0.74 & 0.105 & 602 & 0.73 & 0.128 & 633 & 0.77 & 0.227 \\
\hline Belgium & $12 / 31 / 2005$ & 501 & 1.20 & 0.150 & 886 & 1.08 & 0.168 & 927 & 1.13 & 0.275 \\
\hline Brazil & $12 / 31 / 2010$ & 1,379 & 3.30 & 0.298 & 2,411 & 2.94 & 0.340 & 2,373 & 2.9 & 0.340 \\
\hline Canada & $12 / 31 / 2011$ & 3,099 & 7.41 & 0.129 & 6,126 & 7.46 & 0.162 & 6,564 & 8.03 & 0.248 \\
\hline Chile & $12 / 31 / 2010$ & 767 & 1.83 & 0.091 & 1,204 & 1.47 & 0.105 & 1,205 & 1.47 & 0.149 \\
\hline Denmark & $12 / 31 / 2005$ & 590 & 1.41 & 0.068 & 1,075 & 1.31 & 0.067 & 1,128 & 1.38 & 0.184 \\
\hline Finland & $12 / 31 / 2005$ & 562 & 1.34 & 0.036 & 1,071 & 1.3 & 0.029 & 1,140 & 1.39 & 0.162 \\
\hline France & $12 / 31 / 2005$ & 3,027 & 7.24 & 0.181 & 5,165 & 6.29 & 0.188 & 5,080 & 6.21 & 0.289 \\
\hline Germany & $12 / 31 / 2005$ & 2,108 & 5.04 & 0.174 & 4,298 & 5.24 & 0.239 & 4,432 & 5.42 & 0.294 \\
\hline Greece & $12 / 31 / 2005$ & 506 & 1.21 & 0.137 & 1,151 & 1.4 & 0.191 & 1,208 & 1.48 & 0.211 \\
\hline Hong Kong & $12 / 31 / 2005$ & 363 & 0.87 & 0.036 & 718 & 0.87 & 0.042 & 716 & 0.88 & 0.089 \\
\hline Ireland & $12 / 31 / 2005$ & 139 & 0.33 & 0.010 & 311 & 0.38 & 0.028 & 303 & 0.37 & 0.071 \\
\hline Israel & $12 / 31 / 2008$ & 700 & 1.67 & 0.100 & 1,480 & 1.8 & 0.128 & 1,450 & 1.77 & 0.204 \\
\hline Italy & $12 / 31 / 2005$ & 828 & 1.98 & 0.087 & 1,553 & 1.89 & 0.054 & 1,636 & 2 & 0.226 \\
\hline Malaysia & $12 / 31 / 2012$ & 1,928 & 4.61 & 0.055 & 4,163 & 5.07 & 0.073 & 4,066 & 4.97 & 0.162 \\
\hline Mexico & $12 / 31 / 2012$ & 468 & 1.12 & 0.132 & 810 & 0.99 & 0.147 & 796 & 0.97 & 0.206 \\
\hline Netherlands & $12 / 31 / 2005$ & 622 & 1.49 & 0.133 & 1,235 & 1.5 & 0.157 & 1,264 & 1.55 & 0.230 \\
\hline Pakistan & $12 / 31 / 2007$ & 466 & 1.11 & 0.251 & 1,134 & 1.38 & 0.344 & 1,002 & 1.23 & 0.344 \\
\hline Peru & $12 / 31 / 2012$ & 409 & 0.98 & 0.231 & 672 & 0.82 & 0.300 & 684 & 0.84 & 0.300 \\
\hline Phillipines & $12 / 31 / 2005$ & 382 & 0.91 & 0.148 & 744 & 0.91 & 0.177 & 757 & 0.93 & 0.258 \\
\hline Portugal & $12 / 31 / 2005$ & 211 & 0.50 & 0.131 & 364 & 0.44 & 0.192 & 407 & 0.5 & 0.264 \\
\hline New Zealand & $12 / 31 / 2007$ & 429 & 1.03 & 0.147 & 832 & 1.01 & 0.280 & 802 & 0.98 & 0.280 \\
\hline Nigeria & $12 / 31 / 2012$ & 132 & 0.32 & 0.280 & 314 & 0.38 & 0.300 & 257 & 0.31 & 0.299 \\
\hline Norway & $12 / 31 / 2005$ & 463 & 1.11 & 0.183 & 1,106 & 1.35 & 0.230 & 1,188 & 1.45 & 0.259 \\
\hline Singapore & $12 / 31 / 2005$ & 1,911 & 4.57 & 0.044 & 3,982 & 4.85 & 0.043 & 3,699 & 4.52 & 0.115 \\
\hline Spain & $12 / 31 / 2005$ & 590 & 1.41 & 0.234 & 1,062 & 1.29 & 0.300 & 1,111 & 1.36 & 0.300 \\
\hline South Africa & $12 / 31 / 2005$ & 718 & 1.72 & 0.297 & 1,550 & 1.89 & 0.346 & 1,407 & 1.72 & 0.346 \\
\hline South Korea & $12 / 31 / 2011$ & 3,511 & 8.39 & 0.268 & 6,502 & 7.92 & 0.242 & 6,431 & 7.86 & 0.242 \\
\hline Sri Lanka & $12 / 31 / 2012$ & 196 & 0.47 & 0.263 & 554 & 0.67 & 0.325 & 510 & 0.62 & 0.325 \\
\hline Sweden & $12 / 31 / 2005$ & 1,566 & 3.74 & 0.113 & 2,819 & 3.43 & 0.131 & 2,882 & 3.52 & 0.211 \\
\hline Taiwan & $12 / 31 / 2013$ & 6,777 & 16.20 & 0.036 & 11,664 & 14.21 & 0.027 & 11,190 & 13.68 & 0.094 \\
\hline Turkey & $12 / 31 / 2008$ & 395 & 0.94 & 0.025 & 1,148 & 1.4 & 0.065 & 850 & 1.04 & 0.161 \\
\hline United Kingdom & $12 / 31 / 2005$ & 3,360 & 8.03 & 0.069 & 7,678 & 9.35 & 0.096 & 7,673 & 9.38 & 0.184 \\
\hline Total & & 41,823 & & & 82,091 & & & 81,786 & & \\
\hline
\end{tabular}

Note: Adoption date: mandatory IFRS adoption date for the financial statements closed after December 31 [Deloitte (2015), IFRS Foundation (2017) and PWC (2014)]; $n_{1} n_{2} n_{3}$, number of observations considered in the calculation of the median for variables TA1, TA2, and TA3 (tax avoidance measures), respectively; Percent: percentage of observations for a particular country in relation to the sample.

Source: Elaborated by the authors.

Table 2 presents the descriptive statistics for the variables for the whole sample. The averages for the dependent variables are similar and are $13 \%$ for TA1, $12 \%$ for TA2, and $13.9 \%$ for TA3. Compared with the 8.4\% average found by Atwood et al. (2012), the higher level of tax avoidance for the study sample and period is evident. A reduction in the average corporate income tax rate is noted compared with previous studies. The average tax rate in Atwood et al. (2012) is 37.2\%, in Tang (2015) it is $32 \%$, and in this study, it is $27.7 \%$. This variation may derive from the difference in the countries that compose the sample and the difference in the study periods. The studies mentioned are for 1993-2007 and 1994-2007, respectively, while this study is for 1999-2004. In an (nontabulated) estimation, the average corporate income tax rate for the countries analyzed in this study is $33.06 \%$ in $2000,28.83 \%$ in 2007 , and $26.26 \%$ in 2014 , thus portraying the reduction in the rate over the years. 
Table 2 Descriptive statistic

\begin{tabular}{cccccccc}
\hline Variables & $\mathbf{n}$ & Companies & Mean & Standard Deviation & $\mathbf{1}^{\text {st }}$ quartile & Median & $\mathbf{3}^{\text {rd }}$ quartile \\
\hline TA1 & 41,823 & 9,389 & 0.130 & 0.167 & 0.015 & 0.123 & 0.259 \\
\hline TA2 & 82,091 & 14,766 & 0.120 & 0.210 & 0.002 & 0.160 & 0.290 \\
\hline TA3 & 81,786 & 15,423 & 0.139 & 0.232 & 0.060 & 0.215 & 0.299 \\
\hline TaxRate & 41,823 & 9,389 & 0.277 & 0.060 & 0.245 & 0.280 & 0.330 \\
\hline LegEnf & 41,823 & 9,389 & 1.173 & 0.695 & 0.757 & 1.323 & 1.789 \\
\hline InvRig & 41,823 & 9,389 & 3.878 & 0.847 & 3.000 & 4.000 & 4.500 \\
\hline OwnConc & 41,823 & 9,389 & 0.337 & 0.173 & 0.200 & 0.280 & 0.520 \\
\hline PreTaxROA & 41,823 & 9,389 & 0.105 & 0.088 & 0.046 & 0.082 & 0.137 \\
\hline LogSize & 41,823 & 9,389 & 5.788 & 1.939 & 4.400 & 5.563 & 7.012 \\
\hline Leverage & 41,823 & 9,389 & 0.198 & 0.162 & 0.055 & 0.181 & 0.306 \\
\hline SalesGrth & 41,823 & 9,389 & 0.124 & 0.400 & -0.011 & 0.074 & 0.187 \\
\hline BTaxC & 41,823 & 9,389 & 0.520 & 0.316 & 0.265 & 0.529 \\
\hline TotAcc & 32,538 & 8,396 & 0.000 & 0.107 & -0.044 & 0.001
\end{tabular}

Note: BTaxC: measure of book-tax conformity; companies: number of firms observed; LegEnf: measure of legal enforcement; InvRig: measure of investor rights; Leverage: measure of leverage; LogSize: measure of firm size; OwnConc: measure of ownership concentration; PreTaxROA: measure of profitability; SalesGrth: measure of sales growth; TA1, TA2, TA3: measures of tax avoidance; TaxRate: home-country statutory corporate income tax rate; TotAcc: measure of total accruals.

Source: Elaborated by the authors.

The (non-tabulated) collinearity test was carried out and an average variance inflation factor (VIF) of 1.39 and a highest VIF of 1.57 were found. A VIF below 10 is generally accepted, which suggests that the models used in this study do not present multicollinearity problems. Heteroskedasticity (Wald test) and autocorrelation (Wooldridge test) tests were carried out, which indicated that the models do not present heteroskedasticity and autocorrelation problems.

\subsection{Multivariate Tests}

Table 3 presents the result for the association between IFRS adoption and tax avoidance. Consistent with $\mathrm{H}_{1}$, IFRS adoption is positively associated with tax avoidance for all three forms of measurement of this variable. This result indicates that, on average, the companies started to engage more in tax avoidance after mandatory IFRS adoption.

Consistent with previous studies, it was found that TaxRate is positively associated with tax avoidance, indicating that the higher the corporate income tax rate, the more companies engage in tax avoidance. With regards to the institutional variables, a negative association was found between the LegEnf and OwnConc variables and tax avoidance and a positive association was found between InvRig and tax avoidance. This result suggests that tax avoidance is lower in countries with high legal enforcement and a high ownership concentration, which is in line with previous studies, and higher in countries with high investor protection.

When Slemrod (2004) discusses the economic model of the demand for tax evasion, he presents the probability of detecting evasion and punishment as one of the determining points for deciding to evade tax. In the area of empirical studies, Tang (2015) found that the stronger a country's legal enforcement, the less companies engage in tax avoidance. Atwood et al. (2012), Badertscher, Katz and Rego (2013), and Chen et al. (2010) highlight that companies with a high ownership concentration tend to avoid taxation less. The authors argue that, in general, companies with a high ownership concentration are more concerned with the costs of evading taxes, such as the cost of penalty and of damage to the company's image.

The indication found in this study that high investor protection is associated with greater company engagement in tax avoidance diverges from the results found in previous studies, possibly because of the difference in sample and time of the studies or the way of measuring the variable. In the study from Tang (2015), no significant association was verified between these two variables. Atwood et al. (2012) controlled investor rights with another two institutional characteristics (ownership concentration and legal system) using a factor that was negatively associated with tax avoidance.

In relation to the control variables at the firm level, it was found that companies with a higher PreTaxROA have higher tax avoidance for two of the regressions (1 and 2) and lower tax avoidance for one of the regressions (3). The positive association between PreTaxROA and tax avoidance indicates that more profitable companies engage more in tax avoidance, which is consistent with Atwood et al. (2012), Dyreng et al. (2008), and Rego (2003). The latter highlights that companies with higher pre-tax returns have more incentives and resources to engage in tax planning. The negative association between 
PreTaxROA and tax avoidance identified in regression 3 may derive from the direct relationship between the metrics for these two variables. PreTaxROA takes pre-tax earnings as its numerator, the TA 3 variable takes OCF as its denominator, and pre-tax earnings and OCF have a direct relationship, which can be both negative and positive.

Rego (2003) highlights that bigger companies have a higher effective income tax rate; that is, they engage in less tax avoidance, which is in agreement with the negative association between firm size and tax avoidance found in this study. Atwood et al. (2012) also identified a negative association between LogSize and tax avoidance and showed that this result is consistent with the behavior of bigger companies, which act to reduce potential political costs. As in Atwood et al. (2012), a positive association was found between Leverage and tax avoidance and between Sales Grth and tax avoidance, suggesting that the higher the degree of leverage and the growth in sales of a particular company, the more it engages in tax avoidance.

Table 3 Effects of International Financial Reporting Standards adoption on tax avoidance

\begin{tabular}{|c|c|c|c|c|c|c|}
\hline & \multicolumn{2}{|c|}{ (1) } & \multicolumn{2}{|c|}{ (2) } & \multicolumn{2}{|c|}{ (3) } \\
\hline & \multicolumn{2}{|c|}{ TA1 } & \multicolumn{2}{|c|}{ TA2 } & \multicolumn{2}{|c|}{ TA3 } \\
\hline & Coef. & $t$ & Coef. & $t$ & Coef. & $t$ \\
\hline IFRS & $0.066^{* * *}$ & $(29.566)$ & $0.070^{* * *}$ & $(32.706)$ & $0.060^{* * *}$ & $(25.337)$ \\
\hline TaxRate & $0.7881^{* * *}$ & $(57.07)$ & $0.8268^{* * *}$ & $(63.52)$ & $0.8468^{* * *}$ & $(55.31)$ \\
\hline LegEnf & $-0.0376^{* * *}$ & $(-28.55)$ & $-0.0377^{* * *}$ & $(-31.5)$ & $-0.0261^{* * *}$ & $(-19.42)$ \\
\hline InvRig & $0.0245^{* * *}$ & $(26.23)$ & $0.0236^{* * *}$ & $(27.33)$ & $0.0154^{* * *}$ & $(16.44)$ \\
\hline OwnConc & $-0.1051^{* * *}$ & $(-21.14)$ & $-0.1149^{* * *}$ & $(-24.96)$ & $-0.0663^{* * *}$ & $(-12.68)$ \\
\hline PreTaxROA & $0.1327^{* * *}$ & $(14.55)$ & $0.2172^{* * *}$ & $(29.86)$ & $-0.2071^{* * *}$ & $(-28.06)$ \\
\hline LogSize & $-0.0069^{* * *}$ & $(-16.27)$ & $-0.0099^{* * *}$ & $(-26.48)$ & $-0.0101^{* * *}$ & $(-25.99)$ \\
\hline Leverage & $0.0567^{* * *}$ & $(10.96)$ & $0.0396^{* * *}$ & $(8,92)$ & $0,0658^{* * *}$ & $(15,48)$ \\
\hline SalesGrth & $0.0299^{* * *}$ & $(12.55)$ & $0.0058^{* * *}$ & $(6,253)$ & $0,0046^{* * *}$ & $(5,068)$ \\
\hline Constant & $-0.1389^{* * *}$ & $(-19.15)$ & $-0.1556^{* * *}$ & $(-21,66)$ & $-0,1229^{* * *}$ & $(-14,47)$ \\
\hline Fixed Effect - Year & \multicolumn{2}{|c|}{ Yes } & \multicolumn{2}{|c|}{ Yes } & \multicolumn{2}{|c|}{ Yes } \\
\hline Fixed Effect - Industry & \multicolumn{2}{|c|}{ Yes } & \multicolumn{2}{|c|}{ Yes } & \multicolumn{2}{|c|}{ Yes } \\
\hline $\mathrm{R}^{2}$ & \multicolumn{2}{|c|}{0.247} & \multicolumn{2}{|c|}{0.172} & \multicolumn{2}{|c|}{0.141} \\
\hline $\mathrm{N}$ & \multicolumn{2}{|c|}{41,823} & \multicolumn{2}{|c|}{82,091} & \multicolumn{2}{|c|}{81,786} \\
\hline
\end{tabular}

Note: this table presents ordinary least squares (OLS) regressions that test the effect of IFRS adoption on tax avoidance. The standard errors are robust in terms of heteroskedasticity.

LegEnf: measure of legal enforcement; IFRS: dummy variable for IFRS adoption; InvRig: measure of investor rights; Leverage: measure of leverage; LogSize: measure of firm size; OwnConc: measure of ownership concentration; PreTaxROA: measure of profitability; SalesGrth: measure of sales growth; TA1, TA2, TA3: measures of tax avoidance; TaxRate: home-country statutory corporate income tax rate.

***: $1 \%$ statistical significance.

Source: Elaborated by the authors.

Table 4 presents the result for the association between IFRS adoption and tax avoidance after controlling for book-tax conformity. One of the main arguments of this study is that IFRS adoption can affect levels of tax avoidance because it causes a reduction in the level of book-tax conformity and there is evidence that companies in countries with low conformity present greater tax avoidance. However, the evidence found in this study indicates that there is a positive association between book-tax conformity and tax avoidance; that is, the higher the level of conformity between reported earnings and taxable income, the greater companies' engagement in tax avoidance practices. This association can be explained by the fact that when a company located in a high booktax conformity environment decides to engage in tax avoidance, it can change its accounting choices and report lower accounting earnings in order to pay less tax. Previous studies suggest that firms subjected to a higher level of book-tax conformity alter their accounting choices to avoid taxation costs (Hanlon et al., 2005; Hanlon, Maydew, \& Shevlin, 2008). Thus, in environments of high conformity between reported earnings and taxable income, if a company has more incentives to pay less tax than to report higher profits to the market, it will engage in tax avoidance and consequently reduce its accounting earnings. 
Another possible explanation for the positive association between book-tax conformity and tax avoidance may be due to the loss of an alternative measure of performance when there is high conformity between reported earnings and taxable income, which probably causes a reduction in the ability to detect tax avoidance, given that previous studies have identified the use of book-tax differences to detect tax avoidance (Badertscher, Phillips, Pincus, \& Rego, 2009).

Table 4 Effects of International Financial Reporting Standards adoption on tax avoidance with book-tax conformity control

\begin{tabular}{|c|c|c|c|c|c|c|}
\hline & \multicolumn{2}{|c|}{ (1) } & \multicolumn{2}{|c|}{ (2) } & \multicolumn{2}{|c|}{ (3) } \\
\hline & \multicolumn{2}{|c|}{ TA1 } & \multicolumn{2}{|c|}{ TA2 } & \multicolumn{2}{|c|}{ TA3 } \\
\hline & Coef. & $t$ & Coef. & $t$ & Coef. & $t$ \\
\hline IFRS & $0.063^{* * *}$ & $(28.597)$ & $0.069^{* * *}$ & (32.495) & $0.059^{* * *}$ & $(25.076)$ \\
\hline BTaxC & $0.0567^{* * *}$ & $(16.62)$ & $0.058^{* * *}$ & (19) & $0.0426^{* * *}$ & $(12.82)$ \\
\hline TaxRate & $0.9756^{* * *}$ & $(53.72)$ & $1.016^{* * *}$ & $(62.51)$ & $0.9866^{* * *}$ & $(52.26)$ \\
\hline LegEnf & $-0.0282^{* * *}$ & $(-19.64)$ & $-0.0294^{* * *}$ & $(-22.8)$ & $-0.0198^{* * *}$ & $(-13.55)$ \\
\hline InvRig & $0.0278^{* * *}$ & $(29.41)$ & $0.027^{* * *}$ & $(31.23)$ & $0.0179^{* * *}$ & (19.08) \\
\hline OwnConc & $-0.0987^{* * *}$ & $(-19.98)$ & $-0.1103^{* * *}$ & $(-23.89)$ & $-0.0632^{* * *}$ & $(-12.05)$ \\
\hline PreTaxROA & $0.1497^{* * *}$ & $(16.3)$ & $0.2302^{* * *}$ & $(31.24)$ & $-0.2033^{* * *}$ & $(-27.8)$ \\
\hline LogSize & $-0.0078^{* * *}$ & $(-18.42)$ & $-0.0109^{* * *}$ & $(-28.9)$ & $-0.0109^{* * *}$ & $(-27.65)$ \\
\hline Leverage & $0.0577^{* * *}$ & $(11.16)$ & $0.0407^{* * *}$ & $(9.181)$ & $0.0658^{* * *}$ & $(15.53)$ \\
\hline SalesGrth & $0.0301^{* * *}$ & $(12.51)$ & $0.0061^{* * *}$ & $(6.507)$ & $0.005^{* * *}$ & $(5.52)$ \\
\hline Constant & $-0.2458^{* * *}$ & $(-24.79)$ & $-0.2679^{* * *}$ & $(-28.81)$ & $-0.2045^{* * *}$ & $(-19.34)$ \\
\hline Fixed Effect - Year & \multicolumn{2}{|c|}{ Yes } & \multicolumn{2}{|c|}{ Yes } & \multicolumn{2}{|c|}{ Yes } \\
\hline Fixed Effect - Industry & \multicolumn{2}{|c|}{ Yes } & \multicolumn{2}{|c|}{ Yes } & \multicolumn{2}{|c|}{ Yes } \\
\hline $\mathrm{R}^{2}$ & \multicolumn{2}{|c|}{0.253} & \multicolumn{2}{|c|}{0.175} & \multicolumn{2}{|c|}{0.143} \\
\hline $\mathrm{N}$ & \multicolumn{2}{|c|}{41,823} & \multicolumn{2}{|c|}{82,091} & \multicolumn{2}{|c|}{81,786} \\
\hline
\end{tabular}

Note: this table presents ordinary least squares (OLS) regressions that test the effect of IFRS adoption on tax avoidance, controlling the level of book-tax conformity in the countries. The standard errors are robust in terms of heteroskedasticity.

BTaxC: measure of book-tax conformity; LegEnf: measure of legal enforcement; IFRS: dummy variable for IFRS adoption; InvRig: measure of investor rights; Leverage: measure of leverage; LogSize: measure of firm size; OwnConc: measure of ownership concentration; PreTaxROA: measure of profitability; SalesGrth: measure of sales growth; TA1, TA2, TA3: measures of tax avoidance; TaxRate: home-country statutory corporate income tax rate.

***: $1 \%$ statistical significance.

Source: Elaborated by the authors.

The effect of IFRS adoption on tax avoidance remains the same after the book-tax conformity control. It is noted that the magnitude and direction of the IFRS variable coefficient is similar to the magnitude and direction of the coefficient of this same variable when there was no control for the level of book-tax conformity (Table 3 ). This result indicates that, independent of the level of book-tax conformity required in the country, companies started to engage more in tax avoidance after IFRS adoption.
Table 5 presents the result for the differentiated effect of the association between IFRS adoption and tax avoidance in high and low book-tax conformity environments. Despite the results presented in Table 4 showing that IFRS adoption positively affects tax avoidance independently of the level of book-tax conformity in the country, the results presented in Table 5 show that the positive association between these two variables is different depending on the level of book-tax conformity. 
Table 5 Differentiated effects of International Financial Reporting Standards adoption on tax avoidance in high and low book-tax conformity environments

\begin{tabular}{|c|c|c|c|c|c|c|}
\hline & \multicolumn{2}{|c|}{ (1) } & \multicolumn{2}{|c|}{ (2) } & \multicolumn{2}{|c|}{ (3) } \\
\hline & \multicolumn{2}{|c|}{ TA1 } & \multicolumn{2}{|c|}{ TA2 } & \multicolumn{2}{|c|}{ TA3 } \\
\hline & Coef. & $t$ & Coef. & $t$ & Coef. & $t$ \\
\hline IFRS x HighBTaxC & $0.066^{* * *}$ & $(27.193)$ & $0.076^{* * *}$ & (32.378) & $0.069^{* * *}$ & $(26.307)$ \\
\hline IFRS x LowBTaxC & $0.0605^{* * *}$ & $(23.19)$ & $0.0619^{* * *}$ & $(24.93)$ & $0.0492^{* * *}$ & $(18.13)$ \\
\hline BTaxC & $0.0529^{* * *}$ & $(13.56)$ & $0.0489^{* * *}$ & $(14.18)$ & $0.0299^{* * *}$ & $(7.997)$ \\
\hline TaxRate & $0.9703^{* * *}$ & $(53.2)$ & $1.005^{* * *}$ & $(61.21)$ & $0.9706^{* * *}$ & $(51.29)$ \\
\hline LegEnf & $-0.0284^{* * *}$ & $(-19.72)$ & $-0.0302^{* * *}$ & $(-23.31)$ & $-0.0208^{* * *}$ & $(-14.28)$ \\
\hline InvRig & $0.0279^{* * *}$ & $(29.56)$ & $0.0271^{* * *}$ & $(31.38)$ & $0.0182^{* * *}$ & $(19.35)$ \\
\hline OwnConc & $-0.0987^{* * *}$ & $(-19.98)$ & $-0.1116^{* * *}$ & $(-24.17)$ & $-0.0651^{* * *}$ & $(-12.41)$ \\
\hline PreTaxROA & $0.1499^{* * *}$ & $(16.34)$ & $0.2304^{* * *}$ & $(31.28)$ & $-0.203^{* * *}$ & $(-27.75)$ \\
\hline LogSize & $-0.0078^{* * *}$ & $(-18.44)$ & $-0.0109^{* * *}$ & $(-29.01)$ & $-0.0109^{* * *}$ & $(-27.79)$ \\
\hline Leverage & $0.0577^{* * *}$ & $(11.17)$ & $0.0408^{* * *}$ & $(9.209)$ & $0.0661^{* * *}$ & $(15.59)$ \\
\hline SalesGrth & $0.0301^{* * *}$ & $(12.51)$ & $0.0061^{* * *}$ & $(6.519)$ & $0.005^{* * *}$ & $(5.547)$ \\
\hline Constant & $-0.2951^{* * *}$ & $(-34.52)$ & $-0.2588^{* * *}$ & $(-27.36)$ & $-0.1924^{* * *}$ & $(-18.1)$ \\
\hline Fixed Effect - Year & \multicolumn{2}{|c|}{ Yes } & \multicolumn{2}{|c|}{ Yes } & \multicolumn{2}{|c|}{ Yes } \\
\hline Fixed Effect - Industry & \multicolumn{2}{|c|}{ Yes } & \multicolumn{2}{|c|}{ Yes } & \multicolumn{2}{|c|}{ Yes } \\
\hline $\mathrm{R}^{2}$ & \multicolumn{2}{|c|}{0.253} & \multicolumn{2}{|c|}{0.176} & \multicolumn{2}{|c|}{0.143} \\
\hline $\mathrm{N}$ & \multicolumn{2}{|c|}{41,823} & \multicolumn{2}{|c|}{82,091} & \multicolumn{2}{|c|}{81,786} \\
\hline $\begin{array}{l}\text { Equality of coefficients } \\
\text { tests: IFRS } \times \text { HighBTaxC = } \\
\text { IFRS } \times \text { LowBTaxC }\end{array}$ & \multicolumn{2}{|c|}{$4.93^{* *}$} & \multicolumn{2}{|c|}{$36.50^{* * *}$} & \multicolumn{2}{|c|}{$59.03^{* * *}$} \\
\hline
\end{tabular}

Note: this table presents ordinary least squares (OLS) regressions that test the effect of IFRS adoption on tax avoidance in high and low book-tax conformity environments. It also presents the tests of coefficient equality for the variables IFRS x HighBTaxC and IFRS x LowBTaxC. The standard errors are robust in terms of heteroskedasticity.

BTaxC: measure of book-tax conformity; LegEnf: measure of legal enforcement; IFRS x HighBTaxC: interaction between the dummy variables for IFRS adoption and for countries with a high level of conformity; IFRS x LowBTaxC: interaction between the dummy variables for IFRS adoption and for countries with a low level of conformity; InvRig: measure of investor rights; Leverage: measure of leverage; LogSize: measure of firm size; OwnConc: measure of ownership concentration; PreTaxROA: measure of profitability; SalesGrth: measure of sales growth; TA1, TA2, TA3: measures of tax avoidance; TaxRate: home-country statutory corporate income tax rate.

**, ***: $5 \%$ and $1 \%$ statistical significance, respectively.

Source: Elaborated by the authors.

The tests of coefficient equality reveal that the relationship between mandatory IFRS adoption and tax avoidance is significantly more positive for firms in countries with a high level of book-tax conformity. These results indicate that after IFRS adoption, companies in countries with a higher level of conformity between reported earnings and taxable income started to engage more in tax avoidance than companies in countries with a lower level of conformity. This result can be explained by the fact that when engaging in tax avoidance, companies in countries with high book-tax conformity tend to opt for practices that do not generate book-tax differences (so as not to raise suspicions that the earnings were reported opportunistically), such as transferring profits to jurisdictions with lower tax burdens, and IFRS adoption has facilitated this type of operation. Simone (2015) identified an average increase in profit transfers for tax reasons after IFRS adoption, given that the adoption of a single accounting standard by various countries has facilitated this type of transfer.
Table 6 presents the result for the association between IFRS adoption and tax avoidance controlling for book-tax conformity and total accruals. It is verified that the positive association between mandatory IFRS adoption and tax avoidance persists even when two possible explanatory factors for this relationship are controlled. This result indicates that, keeping the level of book-tax conformity and accruals constant, companies started to engage more in tax avoidance after IFRS adoption.

It is shown in Table 6 that total accruals are positively associated with tax avoidance in two of the regressions ( 1 and 2), which is consistent with Atwood et al. (2012) and indicates that part of the tax avoidance is achieved through accruals. For one of the regressions (3), total accruals are negatively associated with tax avoidance. This negative association can be explained by the inverse relationship between the metrics for these two variables. For the TA3 variable measurement, the higher the OCF, the higher the TA3 variable, and the higher the OCF, the lower total accruals are, thus identifying an inverse 
relationship between the way the TA3 and TotAcc variables are being measured.

It is observed that the result for mandatory IFRS adoption is essentially the same as for mandatory IFRS adoption in the regression in model 1 , when there was no control for accruals. This result suggests that the positive association between IFRS adoption and tax avoidance is not only driven by engagement in tax avoidance through accruals management, but also by other mechanisms that do not involve accruals.

An increase in reported earnings, keeping the value of corporate income tax constant, and depending on the metric used, can result in an increase in tax avoidance, independently of the company being engaged in practices to reduce the value of income tax, which makes the use of total accruals essential for controlling this possible mechanical relationship. The result found indicates that the positive association between mandatory IFRS adoption and tax avoidance does not derive from a mechanical relationship resulting from possible increases in accruals occurring after IFRS adoption.

Table 6 Effects of International Financial Reporting Standards adoption on tax avoidance controlling for book-tax conformity and accruals

\begin{tabular}{|c|c|c|c|c|c|c|}
\hline & \multicolumn{2}{|c|}{ (1) } & \multicolumn{2}{|c|}{ (2) } & \multicolumn{2}{|c|}{ (3) } \\
\hline & \multicolumn{2}{|c|}{ TA1 } & \multicolumn{2}{|c|}{ TA2 } & \multicolumn{2}{|c|}{ TA3 } \\
\hline & Coef. & $t$ & Coef. & $t$ & Coef. & $t$ \\
\hline IFRS & $0.058^{* * *}$ & $(23.085)$ & $0.056^{* * *}$ & $(22.210)$ & $0.046^{* * *}$ & $(17.069)$ \\
\hline BTaxC & $0.056^{* * *}$ & $(14.4)$ & $0.063^{* * *}$ & $(17.03)$ & $0.0427^{* * *}$ & $(10.74)$ \\
\hline TotAcc & $0.0195^{* *}$ & $(2.388)$ & $0.0299^{* * *}$ & $(5.06)$ & $-0.0185^{* * *}$ & $(-3.071)$ \\
\hline TaxRate & $0.9723^{* * *}$ & $(47.21)$ & $1.032^{* * *}$ & $(52.3)$ & $0.9776^{* * *}$ & $(43.73)$ \\
\hline LegEnf & $-0.0246^{* * *}$ & $(-15.26)$ & $-0.0221^{* * *}$ & $(-14.09)$ & $-0.013^{* * *}$ & $(-7.457)$ \\
\hline InvRig & $0.0254^{* * *}$ & $(23.49)$ & $0.0272^{* * *}$ & $(25.85)$ & $0.0157^{* * *}$ & (13.95) \\
\hline OwnConc & $-0.0892^{* * *}$ & $(-15.77)$ & $-0.1026^{* * *}$ & $(-18.29)$ & $-0.0514^{* * *}$ & $(-8.164)$ \\
\hline PreTaxROA & $0.1366^{* * *}$ & $(13.1)$ & $0.2492^{* * *}$ & $(27.05)$ & $-0.2117^{* * *}$ & $(-23.69)$ \\
\hline LogSize & $-0.0081^{* * *}$ & $(-16.74)$ & $-0.0114^{* * *}$ & $(-25.24)$ & $-0.0113^{* * *}$ & $(-24.25)$ \\
\hline Leverage & $0.0622^{* * *}$ & $(10.48)$ & $0.0475^{* * *}$ & $(8.835)$ & $0.0719^{* * *}$ & $(14.5)$ \\
\hline SalesGrth & $0.0303^{* * *}$ & $(10.59)$ & $0.0063^{* * *}$ & $(4.772)$ & $0.0052^{* * *}$ & $(4.094)$ \\
\hline Constant & $-0.2972^{* * *}$ & $(-22.75)$ & $-0.2941^{* * *}$ & $(-26.59)$ & $-0.1784^{* * *}$ & $(-14.72)$ \\
\hline Fixed Effect - Year & \multicolumn{2}{|c|}{ Yes } & \multicolumn{2}{|c|}{ Yes } & \multicolumn{2}{|c|}{ Yes } \\
\hline Fixed Effect - Industry & \multicolumn{2}{|c|}{ Yes } & \multicolumn{2}{|c|}{ Yes } & \multicolumn{2}{|c|}{ Yes } \\
\hline $\mathrm{R}^{2}$ & \multicolumn{2}{|c|}{0.248} & \multicolumn{2}{|c|}{0.175} & \multicolumn{2}{|c|}{0.141} \\
\hline $\mathrm{N}$ & \multicolumn{2}{|c|}{32,538} & \multicolumn{2}{|c|}{57,190} & \multicolumn{2}{|c|}{57,711} \\
\hline
\end{tabular}

Note: this table presents ordinary least squares (OLS) regressions that test the effect of IFRS adoption on tax avoidance controlling by book-tax conformity and total accruals. The standard errors are robust in terms of heteroskedasticity.

BTaxC: measure of book-tax conformity; LegEnf: measure of legal enforcement; IFRS: dummy variable for IFRS adoption; InvRig: measure of investor rights; Leverage: measure of leverage; LogSize: measure of firm size; OwnConc: measure of ownership Concentration; PreTaxROA: measure of profitability; SalesGrth: measure of sales growth; TA1, TA2, TA3: measures of tax avoidance; TaxRate: home-country statutory corporate income tax rate; TotAcc: measure of total accruals.

***: $1 \%$ statistical significance.

Source: Elaborated by the authors.

\subsection{Robustness Tests}

New tests were carried out to verify whether the results are robust for the temporal variation in the tax avoidance metrics proposed by Tang (2015) and the tax enforcement control. The TA2 and TA 3 variables were estimated anually. However, Atwood et al. (2012) argue that there can be a significant variation from one year to the next in the effective tax rate and that considering annual tax avoidance does not minimize the effects of items that are reversed in only one year. Based on these arguments, the TA2 and TA3 variables were estimated over three years and all of the regression models were adjusted for the new tax avoidance variables, with all of the results remaining constant, with the exception of one of the tests of coefficient equality, which did not present any significance.

In order to verify whether the specific enforcement regarding the taxation questions could have an impact on the results found in this study, the legal enforcement metric for the country was substituted by the tax enforcement metric developed by Djankov, Ganser, Mcliesh, Ramalho, \& Shleifer (2010). All of the regression models were adjusted for the tax enforcement variable and the results remained constant, with the exception of one the regressions of model 7 , in which the $B T a x C$ variable lost significance. It should be mentioned that the samples for these tests were a little smaller due to the lack of a tax enforcement variable for Pakistan, the observations for which were excluded from the tests. 


\section{CONCLUSION}

The main aim of this study is to identify the association between mandatory IFRS adoption around the world and levels of tax avoidance. Using three different metrics for tax avoidance and controlling factors at a country and firm level that have shown an association with tax avoidance in previous studies, results were found that suggest an increase in companies' involvement in tax avoidance after mandatory IFRS adoption.

The study also seeks to investigate how the relationship between mandatory IFRS adoption and tax avoidance behaves when the level of book-tax conformity is kept constant, and how this relationship behaves in countries with high and low book-tax conformity. The results found indicate that after mandatory IFRS adoption companies started to engage more in tax avoidance even when the level of conformity between reported earnings and taxable income is kept constant. However, after IFRS adoption, those companies in countries with higher levels of booktax conformity started to engage more in tax avoidance than those in countries with lower levels of book-tax conformity.

This study also aims to discover if IFRS adoption has an impact on companies' engagement in tax avoidance through accruals management practices, practices that do not involve accruals management, or both. The results found indicate that part of the tax avoidance is due to accruals management practices; however, the increase in engagement in tax avoidance by companies after IFRS adoption is also due to other mechanisms that do not involve accruals management, for example, operations in tax havens and profit transfers to subsidiaries in jurisdictions with lower tax burdens.

It is therefore concluded that after mandatory IFRS adoption companies start to engage more in tax avoidance, using both practices that involve accruals management and those that do not. The association between IFRS adoption and increased tax avoidance showed significance independently of the level of book-tax conformity required in the country and the volume of company accruals.

This study contributes to the literature on the effects of IFRS adoption and on the determinants of tax avoidance, as it identifies taxation effects for IFRS adoption and shows that the adoption of one accounting standard is associated with a higher level of company tax avoidance. It also contributes to the current debate about the costs and benefits of different levels of book-tax conformity, by identifying that independently of the level of conformity between reported earnings and taxable income, the level of tax avoidance increased after IFRS adoption. This study presents interesting results for governments, investors, and other market participants, in that it shows greater company engagement in tax avoidance after IFRS adoption.

Hanlon and Heitzman (2010) highlight that the tax avoidance metrics that are used for the effective tax rate, even if measured over the long run, reflect all of the transactions that have any effect on a company's tax liabilities and do not distinguish between real activities that have tax benefits, activities carried out specifically to reduce taxation, and tax benefits obtained via lobbying activities. This factor is presented as a limitation of this study. Another limitation of the study is the lack of any control for the incentives given to managers, given that previous studies have already shown that there is a relationship between these incentives and levels of tax avoidance.

Identifying the effects of IFRS adoption on tax avoidance in environments with different incentives related to institutional factors represents an interesting research opportunity. Previous studies show that IFRS adoption has different effects on the quality of the informational environment, depending on the institutional factors in the countries adopting this set of accounting norms. Thus, institutional factors may determine levels of tax avoidance, since depending on the incentives identified by a company, it may engage in different levels of tax avoidance. 


\section{REFERENCES}

Ahmed, A. S., Neel, M., \& Wang, D. (2013). Does mandatory adoption of IFRS improve accounting quality? Preliminary evidence. Contemporary Accounting Research, 30(4), 13441372.

Atwood, T. J., Drake, M. S., \& Myers, L. A. (2010). Book-tax conformity, earnings persistence and the association between earnings and future cash flows. Journal of Accounting and Economics, 50(1), 111-125.

Atwood, T. J., Drake, M. S., Myers, J. N., \& Myers, L. A. (2012). Home country tax system characteristics and corporate tax avoidance: international evidence. The Accounting Review, 87(6), 1831-1860.

Badertscher, B. A., Katz, S. P., \& Rego, S. O. (2013). The separation of ownership and control and corporate tax avoidance. Journal of Accounting and Economics, 56(2-3), 228-250.

Badertscher, B. A., Phillips, J. D., Pincus, M., \& Rego, S. O. (2009). Earnings management strategies and the trade-off between tax benefits and detection risk: to conform or not to conform? The Accounting Review, 84(1), 63-97.

Brüggemann, U., Hitz, J.-M., \& Sellhorn, T. (2013). Interided and unintended consequences of mandatory IFRS adoption: a review of extant evidence and suggestions for future research. European Accounting Review, 22(1), 1-37.

Chan, K. H., Lin, K. Z., \& Mo, P. L. L. (2010). Will a departure from tax-based accounting encourage tax noncompliance? Archival evidence from a transition economy. Journal of : Accounting and Economics, 50(1), 58-73.

Chan, K. H., Lin, K. Z., \& Tang, F. (2013). Tax effects of booktax conformity, financial reporting incentives, and firm size. Journal of International Accounting Research, 12(2), 1-25.

Chen, E., \& Gavious, I. (2015). The roles of book-tax conformity and tax enforcement in regulating tax reporting behaviour following International Financial Reporting Standards adoption. Accounting and finance (early view; online first). Retrieved from http://dx.doi.org/10.1111/acfi.12172.

Chen, S., Chen, X., Cheng, Q., \& Shevlin, T. (2010). Are family firms more tax aggressive than non-family firms? Journal of Financial Economics, 95(1), 41-61.

De George, E. T., Li, X., \& Shivakumar, L. (2016). A review of the IFRS adoption literature. Review of Accounting Studies, 21(3), 898-1004.

Deloitte (2010). CFO insights: IFRS: select tax considerations. Retrieved from hittp://www.iasplus.com/en/binary/ usa/1012cfotaxconsider.pdf.

Deloitte (2015). Retrieved from http://www.iasplus.com/en/ jurisdictions.

Desai, M. A. (2005). The degradation of reported corporate profits. Journal of Economic Perspectives, 19(4), 171-192.

Djankov, B. S., Ganser, T., Mcliesh, C., Ramalho, R., \& Shleifer, A. (2010). The effect of corporate taxes on investment and entrepreneurship. American Economic Journal: Macroeconomics 2, 2(July), 31-64.

Djankov, B. S., La Porta, R., Lopez-de-Silanes, F., \& Shleifer, A. (2008). The law and economics of self-dealing. Journal of Financial Economics, 88(3), 430-465.
Dyreng, S. D., Hanlon, M., \& Maydew, E.L. (2008). Long-run corporate tax avoidance. The Accounting Review, 83(1), 61-82.

EY. Worldwide corporate tax guide. Retrieved from http://www. ey.com/GL/en/Services/Tax/Worldwide-Corporate-TaxGuide---Country-list.

Frank, M. M., Lynch, L. J., \& Rego, S. O. (2009). Tax reporting aggressiveness and its relation to aggressive financial reporting. The Accounting Review, 84(2), 467-496.

Hanlon, M., \& Heitzman, S. (2010). A review of tax research. Journal of Accounting and Economics, 50(2-3), 127-178.

Hanlon, M., \& Shevlin, T. (2005). Book-tax conformity for corporate income: an introduction to the issues. Tax Policy and the Economy, 19, 101-134.

Hanlon, M., Laplante, K. S., \& Shevlin, T. (2005). Evidence for the possible information loss of conforming book income and taxable income. The Journal of Law and Economics, 48(October 2005), 407-442.

Hanlon, M., Maydew, E. L., \& Shevlin, T. (2008). An unintended consequence of book-tax conformity: a loss of earnings informativeness. Journal of Accounting and Economics, 46(23), 294-311.

IFRS Foundation (2017). Use around the world: analysis of the IFRS jurisdiction profiles. Retrieved from http://www.ifrs. org/Use-around-the-world/Pages/Analysis-of-the-IFRSjurisdictional-profiles.aspx.

IFRS Foundation Constitution (2013). Constitution - Revised and approved by the Trustees. Retrieved from http://www. ifrs.org/The-organisation/Governance-and-accountability/ Constitution/Documents/IFRS-Foundation-ConstitutionJanuary-2013.pdf.

Karampinis, N. I., \& Hevas, D. L. (2013). Effects of IFRS adoption on tax-induced incentivès for financial earnings management: evidence from Greece. The International Journal of Accounting, $48(2), 218-247$

Kaufmann, D.; \& Kraay, A. (2015). The Worldwide Governance Indicators Project. Retrieved from http://info.worldbank.org/ governance/wgi/index.aspx\#home.

KPMG. Tax rates online. Retrieved from http://www.kpmg.com/ global/en/services/tax/tax-tools-and-resources/pages/taxrates-online.aspx.

La Porta, R., Lopez-de-Silanes, F., Shleifer, A., \& Vishny, R. (1998). Law and finance. The Journal of Political Economy, 106(6), 1113-1155.

Lin, S., Riccardi, W., \& Wang, C. (2012). Does accounting quality change following a switch from U.S. GAAP to IFRS? Evidence from Germany. Journal of Accounting and Public Policy, 31, 641-657.

PWC. (2014). IFRS adoption by country. Retrieved from http:// www.pwc.com/us/en/issues/ifrs-reporting/publications/assets/ pwc-ifrs-by-country-2014.pdf.

Rego, S. O. (2003). Tax-avoidance activities of U.S. multinational corporations. Contemporary Accounting Research, 20(4), 805833. 
Simone, L. D. (2015). Does a common set of accounting standards Tax Foundation (2015). Corporate income tax rates around the affect tax-motivated income shifting for multinational firms? Journal of Accounting and Economics, 61(1),145-165.

Slemrod; J. (2004). The economics of corporate tax selfishness. National Tax Journal, LVII(4), 877-899.

Tang, T. Y. H. (2015). Does book-tax conformity deter opportunistic book and tax reporting? An international analysis. European Accounting Review, 24(3), 441-469. world. Retrieved from http://taxfoundation.org/article/ corporate-income-tax-rates-around-world-2014.

The World Bank (2017). GDP ranking. Retrieved from http://data. worldbank.org/data-catalog/GDP-ranking-table.

Wilson, R. J. (2009). An examination of corporate tax shelter participants. The Accounting Review, 84(3), 969-999.

\section{Correspondence address:}

Renata Nogueira Braga

Universidade de São Paulo, Faculdade de Economia, Administração e Contabilidade, Departamento de Contabilidade e Atuária

Avenida Professor Luciano Gualberto, 908 - CEP: 05508-010

Cidade Universitária - São Paulo - SP - Brasil

Email: renatanogueira@usp.br 